\title{
INSTYTUCJONALIZACJA POWIAZZAŃ MIĘDZY UNIĄ EUROPEJSKĄ I PAŃSTWAMI TRZECIMI A SPÓJNOŚĆ
}

Spójność w praktyce europejskiej brana jest pod uwagę przede wszystkim w relacjach wewnętrznych, tzn. w ramach regionów, państw i między państwami tworzącymi rynek wewnętrzny UE. W mniejszym stopniu bierze się pod uwagę procesy zmian strukturalnych zachodzące we Wspólnotach pod wpływem polityki handlowej prowadzonej z krajami trzecimi. Mimo że procesy te nie są opisane, to jednak one zachodzą i polityka prowadzona przez KE ma na celu ich stymulację. Autorka stawia sobie za cel wyjaśnienie pojęcia spójności, wskazanie związków między spójnością a instytucjonalizacją stosunków z państwami trzecimi spoza UE, omówienie ich skuteczności.

\section{Wyjaśnienie pojęcia instytucjonalizacji}

Pojęcie instytucjonalizacji w polskiej literaturze jest dość często stosowane, rzadziej autorzy posługujący się tym określeniem podają jego definicję. Rozbudowaną definicję pojęcia instytucjonalizacji możemy znaleźć w publikacji pod redakcją S. Parzymiesa i R. Zięby z 2004 roku. ${ }^{1}$ Pojęcie instytucjonalizacji wywodzi się z języka łacińskiego od słowa institutio. W języku łacińskim institutio to organizowanie czegoś, albo w szerszym znaczeniu zwyczaj, działanie, które jest powtarzane wielokrotnie, stając się nawykiem. W rozumieniu współczesnym musimy rozróżnić pojęcia instytucji i instytucjonalizacji. Oba są ze sobą ściśle powiązane, jednak pierwotne określenie to instytucja, a następnie wzrost ich roli w życiu społecznym doprowadził do wprowadzenia pojęcia instytucjonalizacji.

Określenie instytucja używane jest w języku polskim w trzech znaczeniach: ${ }^{2}$

- Organizacji, które zajmują się określonym zakresem spraw, prowadzą jakąś działalność, zwłaszcza nieprodukcyjną. Przykładami instytucji tego typu mogą być

${ }^{1}$ Instytucjonalizacja wielostronnej wspólpracy międzynarodowej w Europie, red. S. Parzymies, R. Zięba, Wydawnictwo Naukowe Scholar, Warszawa 2004.

2 Wielki słownik wyrazów obcych PWN, Wydawnictwo Naukowe PWN, Warszawa 2008, s. 550. 
szkoła, bank, urząd. Rozwój instytucji krajowych i ich wpływ na organizację życia w państwach doprowadził do powołania do życia instytucji międzynarodowych. Dzielimy je, stosując różne kryteria, wśród których do najważniejszych można zaliczyć: zasięg geograficzny działania i członkostwa, dziedzinę specjalizacji, formę reprezentacji, sposób finansowania czy zasadę obowiązywania prawa przez nie wprowadzonego.

- Tworzenia zespołu norm prawnych czy obyczajowych, które stanowią podstawy do organizacji jakiejś dziedziny życia. W zależności od poziomu stosowania przyjętych tu regulacji będziemy mówić o normach lokalnych, krajowych, międzynarodowych, regionalnych czy globalnych. Możemy również, stosując kryterium przedmiotowe, mówić o regulacjach dotyczących lotnictwa, przestrzegania praw autorskich czy ruchu drogowego itp.

- „Mianowania” czy „powołania na urząd” - w tym znaczeniu pojęcie to jest rzadziej stosowane i uznaje się je za archaizm.

Jak wspomniano, pojęcie instytucjonalizacji jest pochodną słowa „instytucja” i oznacza czy odnosi się do określania podobnych zjawisk, jak te opisane jako instytucje. Różnica polega na tym, że pojęcie to zawiera w sobie pewien dynamizm procesu, który jest podstawą instytucjonalizacji. Instytucjonalizacja używana jest w dwóch znaczeniach:

- Jest to nadawanie czemuś - jakiemuś działaniu, aktywności, która się powtarza regularnie - charakteru instytucji. Może to odnosić się do różnych działań, poziomów, na których te działania się odbywają (lokalne, centralne, regionalne, subregionalne, globalne). Można również użyć kryterium otwarcia podejmowanych działań, mogą one umożliwiać dołączenie do grupy je podejmującej wszystkich dążących do uczestnictwa w nich, co świadczy o powszechności takiej instytucji. Mogą również dopuszczać tylko tych, którzy spełniają określone warunki (warunkowe). Mogą być obligatoryjne lub dobrowolne. Mogą wreszcie być wyspecjalizowane (problemy finansowe, zdrowia, turystyki czy rozwoju lub bezpieczeństwa). Mogą to być także instytucje o szerszych kompetencjach, jak np. UE czy ONZ. Ich klasyfikacja może również być oparta na kryterium sposobu doboru przedstawicieli i na sposobie wprowadzania rozwiązań prawnych i metodach stosowanych do ich egzekwowania w państwach członkowskich.

- Drugie znaczenie ma charakter socjologiczny, politologiczny lub ekonomiczny i prawny: instytucjonalizacja to „proces utrwalania się uznanych przez społeczeństwo norm i wzorców postępowania oraz uzyskiwania przez nie podstaw organizacyjnych i materialnych".3

3 Ibidem, s. 550. 
Pojęcie instytucjonalizacji występuje - jak można było wydedukować na podstawie definicji tego pojęcia - w różnych naukach społecznych, stanowiąc jedno $\mathrm{z}$ ważniejszych pojęć stosowanych w stosunkach międzynarodowych politycznych i gospodarczych. J. Kukułka uznaje, że pojęcie instytucjonalizacji jest jednym z ważniejszych w stosunkach międzynarodowych. ${ }^{4}$ Proces instytucjonalizacji obejmował początkowo rozwiązania stosowane lokalnie przez plemiona, gdzie określona była hierarchia wynikająca ze starszeństwa lub innych przymiotów posiadanych przez przywódców. Następnie został rozwinięty w procesie tworzenia państw. Kolejnym etapem rozwoju instytucjonalizacji były zasady towarzyszące określaniu systemu prawa międzynarodowego w odniesieniu do handlu zagranicznego, żeglugi na morzach i oceanach, tworzenie koalicji wewnątrz zorganizowanych społeczności oraz w skali międzynarodowej. Obecna faza rozwoju instytucjonalizacji może być uznana za najbardziej zaawansowaną, co jest związane z ewolucyjnymi zmianami w gospodarce światowej, a przede wszystkim stworzenia rozbudowanej sieci norm i instytucji prawnych, w których członkostwo jest pożądane przez większość państw świata. ${ }^{5}$

J. Kukułka przedstawia kilka faz, które zadecydowały o ewolucji procesów instytucjonalizacji. Wskazuje na znaczenie $w$ rozwijaniu procesu instytucjonalizacji następujących działań: ${ }^{6}$

- tworzenie instytucji, norm prawnych, procedur dyplomatycznych;

- zaakceptowanie przez państwa potrzeby tworzenia organizacji międzynarodowych, co miało miejsce po kongresie wiedeńskim 1815 roku;

- sektorowa instytucjonalizacja międzynarodowych stosunków politycznych, kulturowych i gospodarczych;

- stworzenie sieci globalnych rozwiązań instytucjonalno-prawnych, pozwalających rozwijać organizacje regionalne, które opierały zasady swego działania na przyjętych wspólnych normach globalnych; ${ }^{7}$

- powstawanie w drugiej połowie XX wieku wspólnot gwarantujących bezpieczeństwo regionalne, a także integrujących gospodarki regionalne.

W literaturze instytucje często są określane jako reżimy. Część badaczy stosunków międzynarodowych oddziela te dwa pojęcia, traktując je jako przeciwstawne, konkurujące ze sobą koncepcje. Jest to błędne podejście, gdyż pojęcie reżimu to właśnie sieć rozwiązań instytucjonalno-prawnych oraz zasad, które obowiązują

${ }^{4}$ J. Kukułka, Teoria stosunków międzynarodowych, Wydawnictwo Naukowe Scholar, Warszawa 2000, s. 205-209.

${ }^{5}$ R.O. Keohane, Neoliberal institutionalism: A Perspective on World Politics, w: International Institutions and State Power: Essays in International Relations Theory, red. R.O. Kehane, Boulder 1989, s. 3.

${ }^{6}$ J. Kukułka, op.cit., s. 205-209.

7 Uzupełnienie własne do zestawienia cytowanego J. Kukułki i jego teorii stosunków międzynarodowych. 
uczestników danego rozwiązania. Przykładem tego może być chociażby reżim kursu walutowego stosowany przez dane państwo, czy w szerszym znaczeniu reżim pomocy międzynarodowej. Pejoratywne skojarzenia $\mathrm{z}$ pojęciem reżimu $\mathrm{w}$ języku polskim wynikają $\mathrm{z}$ wąskiego stosowania tego określenia. Pojęcie reżim ma jednak dwa znaczenia:

- pejoratywne: „system rządów, w którym władza stosuje wobec społeczeństwa przemoc i ucisk polityczny, odnosi się to również do rządu stosującego takie metody"; w Polsce to pojęcie jest częściej stosowane, co powoduje, że w literaturze na ogół przeciwstawia się pojęcie „reżimu” pojęciu ,instytucjonalizacji”; nie jest to zabieg ani uzasadniony, ani poprawny; wynika przede wszystkim z braku zrozumienia pojęcia; zresztą przeciwstawianie pojęć reżimu i instytucjonalizacji nie znajduje uzasadnienia literaturze i poglądach badaczy stosujących te dwa pojęcia;

- pozytywne: „ścisłe ustalone reguły postępowania w określonych sytuacjach; dyscyplina, a także rygor".

We współczesnej historii przykładem rozbudowanej formy instytucjonalizacji kontaktów wielostronnych państw europejskich była Liga Narodów. Analizując historię Polski, znajdziemy szereg rozwiązań, które opierały się na powiązaniach instytucjonalnych. Przykładem tego może być unia polsko-litewska z 1385 roku. Rozwój dyplomacji konferencyjnej i instytucjonalizacji wielostronnej współpracy nastąpił po II wojnie światowej. J. Kukułka definiował proces instytucjonalizacji następująco: „instytucjonalizacja jest to tworzenie przez państwa trwałych i celowych zespołów oddziaływań (międzynarodowych), stanowiących nowe węzły komunikowania oraz ramy zbiorowego rozpatrywania i rozwiązywania problemów będących wspólnym przedmiotem zainteresowania.".

Opierając się na praktyce, rozróżniamy rozmaite organizacje międzynarodowe oraz odmienne cele, jakim one służą. W zależności od rodzaju zastosowanych form współpracy mamy więc organizacje międzyrządowe, ponadnarodowe i pozarządowe. Wzrost znaczenia organizacji w międzynarodowych stosunkach doprowadził do wzrostu znaczenia multilateralizmu. Organizacje międzynarodowe służą do ustalania zasad, prawa, rozwiązań łagodzących konflikty, określają zasady pokojowego rozwiązywania sporów czy formy karania państw, które łamią wspólnie zaakceptowane zasady postępowania. Organizacje międzynarodowe służą również do koordynowania wspólnych działań. Zakres koordynacji i liczba koordynujących podmiotów stopniowo ulega poszerzeniu.

8 Wielki słownik..., op.cit., s. 1007.

9 Ibidem.

10 J. Kukułka, op.cit. s. 205. 
W stosunkach międzynarodowych stosuje się różne formy koordynacji działań czy polityki w skali międzynarodowej. Można je podzielić na następujące modele:

- follow the leader - podążaj za przywódcą; model działający na zasadzie pozytywnego przykładu (USA, UE);

- koordynacja bezpośrednia, uzgadniana (np. ustalenia dotyczące polityki fiskalnej czy kursowej podejmowanej w ramach określonej grupy państw);

- koordynacja pośrednia $\mathrm{w}$ ramach ustaleń podjętych $\mathrm{w}$ organizacjach międzynarodowych;

- koordynacja otwarta: możesz przystą̧ić do wspólnych działań lub je obserwować. ${ }^{11}$

Zaawansowanie procesów instytucjonalizacji oraz zainteresowanie tą formą współpracy międzynarodowej wyrażone przez państwa może być uznane za czynnik dynamizujący procesy przemian w państwach, w organizacjach międzynarodowych i w stosunkach międzynarodowych. Procesy instytucjonalizacji w stosunkach międzynarodowych obejmują państwa na wszystkich etapach ich rozwoju, dotyczą różnych dziedzin. ${ }^{12}$ Instytucjonalizacja stanowi cechę charakteryzującą współczesne stosunki międzynarodowe w następujących sferach: politycznej, militarnej, gospodarczej, kulturowej, naukowej. ${ }^{13}$

Instytucjonalizacja stosunków zewnętrznych jest rozwiązaniem, które odegrało ważną rolę $\mathrm{w}$ procesach transformacji systemowej rozpoczętych po 1989 roku. ${ }^{14}$ Choć fakt ten jest dość powszechnie akceptowany, w niewielkim stopniu znajduje to odbicie w analizach i opracowaniach odnoszących się do procesów zainicjowanych w 1989 roku w Europie Środkowej i Wschodniej.

Odrębnym problemem, który jest związany z procesem instytucjonalizacji, jest próba wykorzystania więzi międzynarodowych i oddziaływania otoczenia międzynarodowego w dynamizacji przemian instytucjonalno-prawnych (harmonizacja prawa i instytucji) jako warunek członkostwa np. w UE, koordynacja zastosowanych rozwiązań (np. reżimu kursowego, stosowanie kryteriów konwergencji), transfery solidarnościowe i redystrybucja dochodu, stosowanie wspólnej polityki handlowej, co obejmuje handel towarami, usługami, transfer ludzi, kapitału i własności intelektualnej. Uruchomione $\mathrm{w}$ ramach instytucjonalizacji powiązań międzynarodowych procesy sprzyjają wyrównywaniu poziomów rozwoju państw, czego jednym z przejawów jest stosowanie europejskiej polityki kohezji oraz jej ewolucja.

11 K. Żukrowska, Otwarta koordynacja w stosunkach międzynarodowych, Oficyna Wydawnicza SGH, Warszawa 2007.

12 K. Żukrowska, Rola instytucjonalizacji w kształtowaniu stosunków międzynarodowych, Oficyna Wydawnicza SGH, Warszawa 2006.

13 Zmienność i instytucjonalizacja stosunków międzynarodowych, red. J. Kukułka, Warszawa 1998.

14 Transformacja systemowa w Polsce, red. K. Żukrowska, Oficyna Wydawnicza SGH, Warszawa 2010. 


\section{Wyjaśnienie pojęcia spójności}

Pojęcie spójności (cohesion) występuje w wielu dziedzinach, chemii, semantyce, naukach humanistycznych (ekonomii, politologii), geologii. Oznacza w nich wszystkich mniej więcej to samo, co można określić jako „wzajemną przystawalność”, umożliwiającą wzajemne kontakty, wspólne przebywanie, przyciąganie się, komunikację. ${ }^{15}$ W języku polskim angielskie pojęcie cohesion oznacza spójność, przy czym dodaje się zakres tej spójności, określając ją jako społeczną, gospodarczą lub terytorialną. Jest to zawężenie znaczenia tego pojęcia, gdyż w sferze ekonomicznej dotyczy to również spójności strukturalnej, infrastrukturalnej, prawnej czy instytucjonalnej. Spójność to najogólniej pewna jednocząca zgodność, która może występować między ciałami fizycznymi, ich właściwościami (zachowaniami) lub też między pojęciami (obiektami abstrakcyjnymi), np. w rozumowaniu. Pojęcie to używane jest w języku polskim $\mathrm{w}$ filozofii, fizyce, matematyce, metrologii, psychologii czy socjologii. W przypadku UE pojęcie to używane jest w ekonomii, stanowiąc miernik dopasowania wzajemnie do siebie różnych części rynku wewnętrznego UE. W mniejszym stopniu pojęcie to odnosi się do relacji z krajami trzecimi, jednak stosunki zewnętrzne mają bardzo silny wpływ na stan spójności gospodarek państw członkowskich. Przyspieszają pewne procesy, wprowadzając impulsy z zewnątrz, które trudno byłoby wygenerować z taką siłą, posługując się wyłącznie impulsami pochodzącymi z rynku wewnętrznego UE.

Pojęcie kohezji upowszechnione zostało wraz z powołaniem w Unii Europejskiej Funduszu Kohezji w 1993 roku, którego celem była pomoc dla słabszych ekonomicznie krajów członkowskich, później również dla regionów przygranicznych oraz obszarów odległych od regionów centralnych. Jak można się zorientować, problem spójności bezpośrednio odnosi się do rynku wewnętrznego UE, do procesów poszerzania UE, gdzie dąży się do wyrównywania poziomów rozwoju.

Synonimami pojęcia spójność w języku polskim są: kohezja, łączność, spoistość, zwartość, integralność, nierozdzielność, koherencja itp. ${ }^{16}$ Do języka ekonomicznego pojęcie spójności zostało zapożyczone z socjologii. W rozumieniu socjologa określenia spójności używa się w stosunku do grup społecznych, które mogą się komunikować lub nie, stanowią pewną całość, która może być wyodrębniona z otoczenia lub nie właśnie na podstawie określonych cech, które osoby tworzące daną społeczność wyodrębniają ją z otoczenia. A jak problem ten przedstawia się w ekonomii?

15 Wielki słownik..., op.cit., s. 640.

16 Ibidem. 
UE i jej rynek wewnętrzny jest z pewnością wyodrębniony z otoczenia innych państw przez poziom wzajemnych powiązań instytucjonalnych, wspólną politykę handlową, wspólny budżet, a część państw przez wspólną walutę (UGiW). Już wymienienie tych kilku cech decydujących o spójności tego ugrupowania wskazuje na pewne elementy decydujące o spójności, ale równocześnie stanowiące pewne zróżnicowanie państw tworzących jednolity rynek. Te elementy różniące to:

- różny poziom rozwoju;

- różnice w strukturze gospodarczej (gałęziowej);

- różny staż członkowski w UE (państwa inicjatorzy integracji europejskiej, starzy i nowi członkowie, członkowie z różnych fal poszerzenia itp.);

- różne zaangażowanie w finansowanie budżetu UE (beneficjenci netto, płatnicy netto);

- eksporterzy i importerzy kapitału, gospodarki z nadwyżkami na rachunkach bieżących i z deficytami na tychże rachunkach;

- różnice w poziomie bezrobocia;

- różnice interesów w relacjach z krajami trzecimi (czego dowodem są m.in. kierunki polityki sąsiedztwa UE: północny, bałkański, wschodni i śródziemnomorski);

- uczestnictwo w UGiW lub nie, a także w grupie państw nieposługujących się euro: obowiązek uczestnictwa w pogłębianiu lub możliwość stosowania „opcji pozostawania poza" (opt out);

- okresy przejściowe w warunkach członkostwa dla państw nowo wchodzących do UE.

Te różnice można mnożyć. Czy w warunkach tak licznych różnic możemy mówić o spójności grupy stworzonej przez 27 państw europejskich? Czy UE ma potencjał, aby doprowadzić do wyrównania poziomów rozwoju między tą grupą i czy lista różnic, na której zamieszczono tylko kilka najważniejszych, będzie krótsza lub będzie ja można całkowicie wyeliminować?

Eliminacja różnic strukturalnych, społecznych, ekonomicznych i dochodowych jest procesem trudnym. Mimo stosowania środków ze specjalnie przeznaczonego na ten cel funduszu proces wyrównywania poziomów rozwoju między regionami UE zarówno w skali międzynarodowej między państwami członkowskimi, jak i w ramach poszczególnych państw nie przebiega tak, jakby tego oczekiwano w zamierzeniach politycznych państw członkowskich i polityce Unii Europejskiej. Przyczyn tego jest dużo i są one zindywidualizowane. ${ }^{17}$ Przykładowo we Francji, Hiszpanii czy we Włoszech podkreśla się różnice rozwojowe między Północą (bardziej

17 Inwestowanie $w$ region oraz kraje członkowskie UE. Wprowadzenie $w$ życie europejskiej polityki spójności 2007-2013, KE, Dyrektoriat Generalny Polityki Regionalnej, styczeń 2006. 
rozwiniętą) a Południem (reprezentującym na ogół mniej zaawansowany poziom rozwoju). Przyczyn tych różnic upatruje się w migracji ludności, mniejszym zaawansowaniu rozwoju infrastruktury, w tym jednostek edukacyjnych, a także w przypadku Włoch czy Hiszpanii w działaniu struktur mafijnych. Tym samym, mimo przeznaczania znacznych kwot ze środków unijnych na podniesienie poziomu rozwoju $\mathrm{w}$ tych regionach, postęp tego procesu oceniany jest jako powolny i niezadowalający. ${ }^{18}$

Pewne szanse w zakresie zmian tej sytuacji upatrzono w relacjach tych regionów z obszarami zewnętrznymi. Działania w tym zakresie podejmowane są równolegle z procesami stymulowania spójności w ramach regionów i państw członkowskich Unii Europejskiej.

\section{Wyjaśnienie związków między spójnością a instytucjonalizacją}

Proces aktywizacji regionów peryferyjnych $\mathrm{w}$ ramach pogłębiania więzi z krajami spoza Unii Europejskiej nie jest koncepcją nową ${ }^{19}$ Opiera się on na kilku prostych założeniach:

- koncepcji podnoszenia jakości życia jako ważnego czynnika uzyskiwania spójności,

- poprawie spójności terytorialnej,

- tworzeniu modelowych rozwiązań trans regionalnych w zakresie ochrony środowiska, edukacji, infrastruktury,

- współpracy nad rozwiązaniem problemu zaopatrzenia w energię,

- modelu otwartych rozwiązań dla spędzania wolnego czasu.

To kilka koncepcji sprzyjających poprawie spójności obszarów peryferyjnych UE, w których ważnym elementem jest współpraca z krajami sąsiedzkimi. W rozwiązaniach mających na celu poprawę spójności, w których uwzględnia się kraje spoza UE, ważnym elementem staje się proces instytucjonalizacji wzajemnych relacji państw członkowskich UE z państwami trzecimi. Ważne również jest to, że w opracowaniach analizujących wzajemne relacje państw członkowskich i pozaczłonkowskich problem spójności nie jest rozpatrywany jako zjawisko mające związek z poprawą spójności w UE, ale jako zjawisko poprawy spójności między państwem sąsiedzkim a UE. Podejście takie ma uzasadnienie w fakcie dużej

18 Simplyfying Cohesion Policy for 2014-2020, ECE, February 2012.

19 I. Bache, Europeization and and Multilevel Governance. Cohesion Policy in the European Union and Britain, Rowan, Littlefield 2008. 
podejrzliwości państw trzecich, że bliższe kontakty z nimi są dyktowane wyłącznie egoistycznym interesem gospodarek reprezentujących wyższy poziom rozwoju.

Niemniej nie ulega wątpliwości, że zgodnie z koncepcją aktywizacji ośrodków peryferyjnych tworzenie możliwości dla ich bliższych kontaktów z otoczeniem międzynarodowym jest rozwiązaniem stanowiącym warunek ich ożywiania i rozwoju. Instytucjonalizacja wymaga budowy infrastruktury, wpływa na zwiększenie ruchu turystycznego, ożywia wzajemne kontakty gospodarcze, sprzyja rozwijaniu przedsiębiorczości i usług. Podejmowane w tym zakresie działania wywierają bezpośredni wpływ na wzrost gospodarczy, zatrudnienie i rzutują na wyrównywanie poziomów rozwoju. ${ }^{20}$

Założenie stojące za takim rozwiązaniem jest proste: terytoria, obszary charakteryzujące się peryferyjnością wobec obszaru stanowiącego zintegrowaną całość tracą znaczenie peryferyjności wraz z poszerzeniem tego obszaru. Formą poszerzania jest zwiększanie liczby członków UE, uzupełnieniem tej formy jest instytucjonalizacja kontaktów gospodarczych, finansowych, kulturowych z obszarami granicznymi lub pozamorskimi. Taki proces instytucjonalizacji stanowi jeden z efektywniejszych czynników stymulujących rozwój obszarów charakteryzujących się niższymi parametrami rozwojowymi i wzrostowymi. Jest to rozwiązanie hamujące odpływ mieszkańców, z czasem przyciągające procesy osadnicze na danym obszarze. ${ }^{21}$

Ważnymi elementami stymulującymi wzajemne kontakty między obszarami peryferyjnymi UE a państwami sąsiedzkimi obok procesu instytucjonalizacji stosunków są:

- polityka sąsiedztwa;

- instrumenty finansowe stosowane w ramach polityki sąsiedztwa;

- zastosowane rozwiązanie decydujące o zasadach podziału środków przy realizowaniu programów finansowanych w ramach polityki sąsiedztwa, w których wiodącą rolę odgrywają ośrodki zlokalizowane w UE, w tym konkretnym przypadku ośrodki peryferyjne. ${ }^{22}$

Problem ten, choć znajduje potwierdzenie w zastosowanych rozwiązaniach instytucjonalno-prawnych i finansowych, nie znalazł większego odbicia w przeprowadzonych analizach. Można powiedzieć, że zarówno praktyka, jak i szersza analiza modelowo-teoretyczna i empiryczna czekają na swój czas. Procesy wskazane w tym

20 Community Strategic Guidelines for Cohesion 2007-2013.

21 General Provisions ERDI-ESF - Cohesion Fund 2007-2013.

22 R.H. Ginsberg, Demistifying European Union: The Enduring Logic of Regional Integration, Rowan, Littlefield 2007. 
krótkim opracowaniu są zaledwie zasygnalizowane, niemniej stanowią interesujący temat do dalszych analiz i badań. ${ }^{23}$

Znaczenie spójności i instytucjonalizacji dla polityki makrostabilizacyjnej czy kohezji znajduje odzwierciedlenie w strategii Europa 2020. Widoczne jest również $\mathrm{w}$ zasadach towarzyszących podziałowi środków, uzgodnionych na szczycie 7-8 lutego 2013 roku w Brukseli.

\section{Postanowienia szczytu 7-8 lutego 2013 roku}

Herman van Rompuy określił szczyt jako jeden z najcięższych i trudnych. Negocjacje rozpoczęły się z pewnym opóźnieniem i trwały z małą przerwą całą noc. W nocy zarządzono dwugodzinną przerwę, która umożliwiła szczegółową analizę zaproponowanych rozwiązań, a są one dość skomplikowane. Niemniej jednak szczyt zakończył się porozumieniem i, co może dziwić, ich rezultat został przyjęty z zadowoleniem przez głównych negocjatorów. Jakie rozwiązanie doprowadziło do porozumienia i zostało zaakceptowane przez wszystkich, a nawet oceniono je jako sukces poszczególnych delegacji narodowych? Ma to szczególne znaczenie w kontekście głębokich różnic, które dzieliły państwa członkowskie i ich negocjatorów listopadzie 2012 roku, prowadząc do zerwania negocjacji.

Postanowienia szczytu nie są ostatecznym rozwiązaniem. Aby ustalenia uzyskały status dokumentu UE, który będzie obowiązywał w latach 2014-2020, wymagają zatwierdzenia przez Parlament Europejski. Martin Schultz, przewodniczący PE, zapowiada, że to dopiero początek procesu przyjmowania nowych ram finansowych. Choć w listopadzie 2012 roku nie przewidywano większych problemów z przyjęciem nowych ram w Parlamencie, obecnie pojawiło się kilka zastrzeżeń, które mogą wydłużyć proces przyjmowania tego dokumentu. Po pierwsze, mówi się, że nowe ramy powinny wprowadzić tzw. klauzulę przeglądową, co może prowadzić do kontroli sposobu wykorzystania udostępnionych środków na „półmetku” realizacji ram, czyli w 2017 roku. W warunkach stwierdzenia ograniczonej gospodarności wykorzystania środków prowadziłoby to do odebrania części środków. Inne zastrzeżenia Parlamentu do przyjętych na szczycie ram finansowych można przedstawić $\mathrm{w}$ trzech punktach. Po pierwsze, uzgodnione warunki finansowania UE na lata 2014-2020 w ograniczonym stopniu korespondują z priorytetami, które sformułowano

23 R. Berger-Schmitt, Social Cohesion and the aspect of Quality of the Societies: Concept and Measurement, EU Reporting WP No. 14, Manheim 2000. 
w strategii Europa 2020. Po drugie, Parlament może zażądać zmian w zasadach sfinansowania budżetu, co może oznaczać próbę wprowadzenia nowych źródeł. Przykładem takiego nowego źródła jest opodatkowanie transakcji finansowych, sprawa już wcześniej dyskutowana w UE. Na razie 11 państw wyraża zgodę na wprowadzenie tego rozwiązania. Ponadto można myśleć o zastąpieniu „źródeł własnych” finansowania budżetu, które są własne tylko z nazwy, przez de facto „źródła własne”, co oznaczałoby wprowadzenie bezpośrednich podatków wpłacanych do budżetu ogólnego. Po trzecie, PE może starać się o ograniczenie finansowania części celów, przesuwając wydatki na inne cele. Po czwarte, podkreśla się, że tak szybko zmieniające się warunki gospodarowania wymagają szybkiej reakcji, a ramy siedmioletnie tego nie gwarantują, a więc należałoby przyjąć je na mniej niż siedem lat. Taką możliwość gwarantuje Traktat lizboński, w którym dopuszcza się ramy o krótszym okresie obowiązywania. W ocenie M. Schultza przyjęte ramy są bardzo konserwatywne i nie odpowiadają na wyzwania, które niosą obecne warunki rozwoju, wywołane pojawieniem się rynków wschodzących, masowym procesem przenoszenia produkcji do państw Azji, wysokim poziomem bezrobocia, czy kryzysem finansowym strefy euro.

Są to oceny sformułowane na gorąco. Trudno przewidzieć, jak wydarzenia potoczą się podczas przyszłej debaty w Parlamencie Europejskim. M. Schultz, obawiając się silnych nacisków rządów na swoich eurodeputowanych, które mogą skutecznie obniżyć ostrze krytyki i samodzielność podejmowania decyzji, zapowiada zastosowanie procedury tajnego głosowania. W uzasadnieniu decyzji używa argumentu, że jest to jeden z bardziej zachowawczych budżetów wieloletnich, choć sytuacja wymaga przełomu.

\section{Założenia przyjęte na szczycie 7-8 lutego 2013 roku}

Budżet po stronie wydatków tworzy sześć pozycji, które w szczegółowym rozpisaniu podzielone są dodatkowo na mniejsze, bardziej szczegółowe pozycje. Zmiany wynikające z porównań kolejnych wieloletnich ram finansowych pozwalają prześledzić zmiany w priorytetach finansowych Komisji Europejskiej. Największe pozycje w budżecie to środki finansujące "zarządzanie zasobami naturalnymi i ich ochrona” oraz „spójność na rzecz wzrostu i zatrudnienia”. 
Tabela 1. Wieloletnia Perspektywa Finansowa 2007-2013 i Wieloletnie Ramy Finansowe 2014-2020 uzgodnione na szczycie 7-8 lutego 2013 roku (zaokrąglenia podane $\mathrm{w}$ mld euro)

\begin{tabular}{|l|c|c|c|}
\hline \multicolumn{1}{|c|}{ Struktura wydatków } & $\begin{array}{c}\text { WPF } \\
2007-2013\end{array}$ & $\begin{array}{c}\text { WRF } \\
2014-2020\end{array}$ & $\begin{array}{c}\text { Obserwowana } \\
\text { zmiana }\end{array}$ \\
\hline $\begin{array}{l}\text { Konkurencyjność na rzecz wzrostu i zatrudnienia (inwestycje, } \\
\text { m.in. na badania naukowe, wymianę studentów, Erasmus, } \\
\text { i pracowników) }\end{array}$ & 89 & 126 & wzrost \\
\hline $\begin{array}{l}\text { Spójność na rzecz wzrostu i zatrudnienia (pomoc słabszym } \\
\text { regionom w pokonywaniu luki rozwojowej, współpraca } \\
\text { transgraniczna) }\end{array}$ & 348 & 325 & spadek \\
\hline $\begin{array}{l}\text { Zarządzanie zasobami naturalnymi i ich ochrona (dopłaty } \\
\text { dla rolników, rozwój terenów wiejskich, ochrona środowiska) }\end{array}$ & 413 & 373 & spadek \\
\hline $\begin{array}{l}\text { Obywatelstwo, wolność i sprawiedliwość (polityka } \\
\text { imigracyjna, walka z przestępczością, ochrona konsumenta, } \\
\text { programy kulturalne) }\end{array}$ & 12 & 16 & wzrost \\
\hline $\begin{array}{l}\text { UE jako partner globalny (pomoc humanitarna, } \\
\text { programy z sąsiednimi państwami) }\end{array}$ & 56 & 60 & wzrost \\
\hline Administracja & 56 & 62 & wzrost \\
\hline Zobowiązania & 975 & 960 & spadek \\
\hline Płatności & 925 & 908 & spadek \\
\hline
\end{tabular}

Źródło: Komisja Europejska, www.euopa.eu

Zaprezentowane wielkości powstały w oparciu o ceny (poziom inflacji) w 2011 roku. Co roku są one poddawane automatycznej korekcie, w której uwzględnia się inflacyjny wzrost cen. Tym samym inflacja nie jest czynnikiem, który może wpłynąć na redukcję transferów. Zmiany w wartości transferów może natomiast spowodować kurs waluty euro i waluty narodowej państwa, które nie należy do UGiW. Przykładowo, jeśli kurs euro będzie podlegał aprecjacji, to transfery mogą rosnąć, jeśli kurs waluty krajowej będzie podlegał aprecjacji z niższą dynamiką lub będzie podlegał deprecjacji. Zmniejszą się, jeśli kurs będzie podlegał aprecjacji z większą dynamiką od aprecjacji euro. Transfery nie ulegną natomiast zmianie dla państw posługujących się tą samą walutą, w jakiej transfery są dokonywane. Zmiany kursu waluty narodowej i euro mają również wpływ na transfery w drugą stronę, tzn. do budżetu ogólnego.

Przedstawione zestawienie wskazuje na spadek środków przeznaczonych na konkurencyjność na rzecz wzrostu i zatrudnienia, a także zarządzanie zasobami naturalnymi i ich ochronę. Środki przeznaczone na pozostałe pozycje zostały zwiększone. Ostateczna alokacja zależy od szczegółowych zapisów dotyczących podzialów środków w ramach przedstawionych sześciu celów wydatków. Wynik ostateczny obu zestawień wskazuje na spadek płatności i zobowiązań przewidywanych w WRF 
2014-2020 w porównaniu z WPF 2007-2013. Zestawienie potwierdza w statystykach to, co zapowiedzieli politycy, którzy domagali się przeprowadzenia cięć. Należy podkreślić, że cięcia te są głębsze ze względu na inflację.

Ustalone zasady podziału środków biorą pod uwagę poziom rozwoju regionu i uzyskiwane w nim dochody na głowę ludności.

W konluzjach ze szczytu podaje się kilka programów, które uzyskują odrębne finansowanie. Dotyczą one hasła określanego jako „łączenie Europy” (connecting Europe). Są to:

- transport - 23174 mln euro (z czego 100000 mln pochodzi z Funduszu Spójności i będzie wykorzystane zgodnie z zasadami określonymi dla państw, które mogą ze środków tego funduszu korzystać),

- energia - 5126 mln euro,

- telekomunikacja - 1000 mln euro.

Obok wymienionych projektów podkreśla się znaczenie projektów infrastrukturalnych, na które przeznacza się odpowiednio:

- Galileo - 6300 mln euro,

- ITER - 2707 mln euro,

- GMES - 3786 mln euro.

Przeznacza się również 0,35\% ogólnego poziomu środków na pomoc techniczną. Będą one przeznaczone na wzmocnienie instytucji i poprawy potencjału administracyjnego, co ma sprzyjać lepszemu zarządzaniu środkami i ich wykorzystaniu na finansowanie zidentyfikowanych projektów operacyjnych, które odpowiadają na obecne wyzwania stojące w gospodarkach tworzących rynek wewnętrzny.

$330 \mathrm{mln}$ funduszy strukturalnych przeznacza się na inwestycje, które mają stymulować tworzenie miejsc pracy i sprzyjać tworzeniu warunków dla zrównoważonego wzrostu.

W konkluzjach sprecyzowano, które kraje mają uprawnienia do korzystania z dostępnych środków i na jakich zasadach. Dokument wprowadza trzy grupy państw i określa zasady, które decydują o zaklasyfikowaniu poszczególnych państw do wymienionych kategorii. Oznacza to podział regionów państw na trzy zasadnicze grupy, w których za kryterium przyjęto poziom dochodów na głowę: ${ }^{24}$

- regiony określane jako reprezentujące niższy poziom rozwoju, o czym decyduje ich PNB na głowę niższy od 75\% dla UE-27;

- regiony w procesie przemian, w których PNB per capita zawiera się między 75\% a 90\% średniego poziomu dla UE-27;

24 Wielkość dochodów liczona jest w parytecie siły nabywczej. 
- bardziej rozwinięte regiony, w których PNB na głowę kształtuje się powyżej 90\% średniego poziomu dla UE-27.

Ze środków Funduszu Spójności będą mogły korzystać regiony, w których PNB na głowę, mierzony w parytecie siły nabywczej (PPP) w oparciu o dane statystyczne Eurostatu w latach 2008-2010, kształtował się poniżej 90\% jego poziomu skalkulowanego dla państw UE-27.

W dokumencie podkreśla się znaczenie projektów współpracy o charakterze działań transgranicznych, międzynarodowych, międzyregionalnych. Każde państwo członkowskie uzyska określony poziom alokacji, opartej na przyjętych, obiektywnych zasadach. Alokacje dla każdego państwa to suma alokacji dla jego poszczególnych regionów, obliczona w oparciu o następujące zasady:

- Określenie kwoty ogólnie dostępnych transferów przez pomnożenie liczby mieszkańców regionu przez różnicę między poziomem dochodów na głowę w regionie (mierzoną w parytecie siły nabywczej) i średniej dla UE-27 (również mierzonej w parytecie siły nabywczej).

- Zastosowanie udziału procentowego, stanowiącego wynik powyższych obliczeń do określenia wielkości transferów dla danego regionu. Określa to zamożność relatywną regionu i może być porównane ze średnią dla UE-27, państw, w których dany region jest zlokalizowany. Ta wstępna kalkulacja pozwala zastosować określone pułapy procentowe transferów według przyjętych zasad: (1) dla regionów krajów członkowskich, których PNB na głowę jest niższy niż 82\% UE, na poziomie 3,15\%; (2) dla regionów państw członkowskich, w których PNB kształtuje się między $82 \%$ a 99\% - średnio na poziomie 2,70\%; (3) dla regionów państw członkowskich, których poziom PBN na głowę kształtuje się na poziomie przekraczającym 99\% - średnio 1,65\%.

- Do kwot uzyskanych w punkcie (2) powyżej dodaje się, jeśli jest to zgodne z przyjętymi zasadami, sumę alokacji dodatkowej wynoszącą 1300 euro na osobę niezatrudnioną na rok. Rozwiązanie to stosuje się dla liczby osób bezrobotnych w regionie, która przewyższa wielkość bezrobocia w warunkach średniego wskaźnika bezrobocia stosowanego w całej UE o niższym poziomie rozwoju.

- Nie przewiduje się zastosowania dodatkowych transferów środków w ramach premii dla miast.

Wprowadza się specjalne zasady alokacji dla regionów w procesie przemian. Metoda ta jest obiektywna i opiera się na założeniach wprowadzonych dla każdego regionu, na co składają się następujące posunięcia:

- Określenie zakładanego przedziału z poziomem minimalnym i maksymalnym intensywności pomocy dla każdego uprawnionego do jej otrzymywania regionu, który znajduje się w procesie przemian. Minimalny poziom wsparcia określony jest 
dla każdego z państw członkowskich, zanim określi się 60\% alokację bezpieczeństwa dla regionów gospodarek reprezentujących wyższy poziom rozwoju. Górny pułap, określany jako maksymalny poziom wsparcia, odnosi się do teoretycznego regionu, w którym PNB na głowę kształtuje się na poziomie $75 \%$ średniego wyliczonego dla UE-27. Przeprowadzona tu kalkulacja powinna opierać się na zasadach sformułowanych w kroku (1) i (2), które przedstawiono wyżej.

- Obliczenia wstępnych alokacji regionalnych, w których bierze się pod uwagę PNB na głowę w efekcie linearnej interpretacji względnej zamożności regionu, uwzględniającej jej poziom dla UE-27.

- Do kwoty uzyskanej w ramach kroku (2) dodawana jest, jeśli jest to zgodne z przyjętymi zasadami, dodatkowa premia w wysokości 1100 euro na każdego bezrobotnego w tym regionie powyżej poziomu bezrobocia uwzględniającego średni jego wskaźnik dla państw członkowskich UE skalkulowany dla mniej rozwiniętych regionów.

- Nie przewiduje się stosowania dodatkowych premii dla miast.

Przewiduje się stosowanie innych metod dla bardziej rozwiniętych regionów. Przyjmuje się tu zasadę, że szacunek ogólnego poziomu transferów określa się przez pomożenie intensywności wsparcia w jego wymiarze na głowę w ciągu roku przez 19,8 euro dla ludności, która objęta jest tym wsparciem. Jeśli zaś chodzi o udział każdego z państw członkowskich w ogólnej kwocie wsparcia, określonej w oparciu o wskaźniki dla ich regionów, które do niego się kwalifikują, to stosuje się następującą zasadę:

- ogólny poziom ludności (waga 25\%);

- liczba zatrudnionych w jednostek NUTS ${ }^{25}$ na poziomie 2 regionów, w których wskaźnik bezrobocia kształtuje się powyżej średniego dla wszystkich rozwiniętych regionów (waga 20\%);

- liczba utworzonych miejsc pracy, jakie powinny powstać, aby uzyskać poziom celu regionalnego zakładanego w strategii Europa 2020 (dla przedziału wieku 20-64) wynoszący $75 \%$ (waga 20\%);

- określenie liczby ludności w wieku 30-34 z trzecim poziomem edukacji, która powinna prowadzić do uzyskania zakładanych celów przyjętych w strategii Europa 2020 - wynoszących $40 \%$ (waga 12,5\%);

- określenie liczby osób opuszczających system edukacji, definiowanych jako wcześnie porzucające naukę ( $w$ wieku $18-24$ ), pozwalającej uzyskać poziom wyznaczony przez strategię Europa 2020 w wysokości 10\% (waga 12,5\%);

25 NUTS - europejska klasyfikacja jednostek terytorialnych państw członkowskich UE dla celów statystycznych (fr. Nomenclature des Unites Territoriales Statistique, ang. Nomenclature of Units for Territorial Statistics). 
- różnica między uzyskanym poziomem PNB regionu (szacowanego w parytecie siły nabywczej) i teoretycznym regionalnym poziomem PNB, jeśli w regionie poziom PNB kształtowałby się na poziomie najbardziej zamożnych regionów w grupie NUTS2 (waga 7,5\%);

- liczba ludności w regionach zaliczanych do $\mathrm{NUTS}^{26} \mathrm{z}$ gęstością zaludnienia poniżej 12,5 mieszkańca/ $/ \mathrm{km}^{2}$ (waga 2,5\%).

Podkreśla się tu również, podobnie jak w przypadku regionów o niższych dochodach, brak możliwości stosowania premii dla miast.

Tabela 2. Tytuł 1a i 1b propozycji WRF 2014-2020 przyjętych na szczycie 7-8 lutego 2013 roku

\begin{tabular}{|c|c|c|c|c|c|c|c|}
\hline \multicolumn{7}{|c|}{ 1a. Konkurencyjność na rzecz tworzenia miejsc pracy (w mln euro, w cenach 2011) } \\
\hline 2014 & 2015 & 2016 & 2017 & 2018 & 2019 & 2020 & $2014-2020$ \\
\hline 15605 & 16321 & 16726 & 17693 & 18490 & 19700 & 21079 & 125614 \\
\hline \multicolumn{7}{|c|}{ 1b. Spójność gospodarcza, społeczna i terytorialna (w mln euro, w cenach 2011) } \\
\hline 44678 & 45404 & 46045 & 46545 & 47038 & 47514 & 47925 & 325149 \\
\hline
\end{tabular}

Źródło: Conclusions WRF. EUCO 37/13 CONCL3, Brussels, 8.02.2013.

Środki przeznaczone na inwestycje we wzrost i tworzenie miejsc pracy szacowane są w WRF na 313197 mln euro, co podlega podziałowi między poszczególne regiony według ich poziomu rozwoju:

a) Ogólna kwota 164279 mln euro dla regionów reprezentujących niższy poziom rozwoju:

- 31677 mln euro dla regionów w procesie przemian,

- 49492 mln euro dla bardziej rozwiniętych regionów,

- 66362 mln euro dla państw członkowskich, finansowane z Funduszu Spójności.

b) Ogólna kwota $1387 \mathrm{mln}$ euro dodatkowo przeznaczona jest na finansowanie regionów określonych w art. 349 Traktatu oraz północnych, spełniających kryteria niskiej gęstości zaludnienia określonych w art. 2 Protokołu 6 Traktatu o członkostwie Austrii, Finlandii i Szwecji.

${ }^{26}$ NUTS podzielone są na trzy grupy, do których klasyfikacja oparta jest na przyjętych progach populacji zamieszkujących dany obszar, ustalona dla danego państwa. NUTS1 to 3-7 mln ludności, NUTS2 to 0,8-3 mln, a NUTS3 - 150 000-800 000. Przykładowo w Polsce mamy obecnie 6 jednostek zakwalifikowanych na poziomie NUTS1, 16 - na poziomie NUTS2 i 66 - na poziomie NUTS3. Wcześniej stosowano podział na większą liczbę NUTS i posługiwano się innymi kryteriami. Klasyfikacja NUTS została wprowadzona w 1988 roku. W 2003 roku przyjęto rozporządzanie w sprawie NUTS, a w roku 2005 znowelizowano te przepisy, wprowadzając 10 nowych państw członkowskich. Klasyfikacja NUTS może być zmieniana, jednak nie częściej niż co trzy lata. Pierwsza klasyfikacyjna zmiana została wprowadzona w styczniu 2008 roku, druga w styczniu 2012 roku. 
Na cel określony jako współpraca terytorialna w Europie przeznacza się ogólną kwotę wartości 8948 mln euro, która zostaje podzielona w następujący sposób:

- ogólna kwota 6627 mln euro na współpracę transgraniczną,

- 1822 mln euro na współpracę międzynarodową,

- 500 mln euro na współpracę międzyregionalną.

Metody przyjęte dla alokacji środków z Funduszu Spójności również nie są proste, ale przejrzyste, i zastosowano w nich podobne zasady naliczania jak w przypadku definiowania zasad ogólnej dostępności środków. Ogólny poziom środków dostępnych dla każdego państwa członkowskiego uzyskuje się przez pomnożenie średniej intensywności pomocy szacowanej na 48 euro przez liczbę ludności. Przed określeniem poziomu alokacji każde państwo członkowskie uprawnione do nich odnosi się do teoretycznych alokacji, które są określone na podstawie liczby ludności, zamożności, wielkości terytorium, co przeprowadzone jest zgodnie z następującymi zasadami: - Wyliczenie oparte na udziałach średniej arytmetycznej liczby ludności i obszaru terytorium w stosunku do liczby ludności i wielkości całego obszaru wszystkich państw UE. Jeśli udział liczby ludności przekroczy jego udział w obszarze o 5 lub więcej, co będzie świadczyło o wysokiej gęstości zamieszkania, kraj taki może posługiwać się tylko wskaźnikiem udziału ludności w swych kalkulacjach, pomijając drugi wskaźnik.

- Korekta uzyskanych udziałów liczonych procentowo powinna uwzględniać współczynnik 1/3 udziału procentowego, o który PNB na głowę danego kraju w okresie 2008-2010 przewyższa, lub kształtuje się poniżej średniej PNB na głowę wszystkich państw uprawnionych do korzystania z tych środków (przyjmuje się, że średnia ta wynosi 100\%).

- W związku z potrzebą uwzględnienia potrzeb odnoszących się do rozwoju transportu i związanej z tym rozwojem infrastruktury telekomunikacyjnej oraz ochrony środowiska nowych państw członkowskich, którzy dołączyli do UE w 2004 roku i później, uwzględnia się wyższy ich udział w Funduszu Spójności. Oznacza to przyjęcie wskaźnika $1 / 3$ całkowitej alokacji po uwzględnieniu zasady wprowadzenia pułapów dla funduszy strukturalnych i kohezji, zgodnych z przyjętymi zasadami.

- Państwa, które w pełni były uprawnione do korzystania z Funduszu Spójności w latach 2007-2013, ale których nominalny poziom PNB na głowę przekracza 90\% średniego wskaźnika PNB na głowę dla UE-27, będą mogły skorzystać ze wsparcia z Funduszu Spójności w okresie przejściowym i na specjalnych zasadach. To wsparcie wyniesie 48 euro na głowę w 2014 roku i stopniowo będzie ulegało redukcji, aż do pełnej eliminacji do 2020 roku. 
- Przyjęte zasady objęte są mechanizmem cięć transferów na rzecz państw członkowskich po przekroczeniu określonego jego poziomu (capping).

Wprowadza się specjalne warunki i zasady finansowania rzadko zamieszkałych obszarów, obszarów określonych jako oddalone oraz dla wysp. W przypadku regionów oddalonych i rzadko zaludnionych zakwalifikowanych do NUTS2 przewiduje się specjalną alokację wynoszącą 30 euro na mieszkańca rocznie. Środki te będą przekazane regionom w państwach członkowskich proporcjonalnie do ogólnej liczby zamieszkującej je ludności. Kalkulacja ta musi również brać pod uwagę specjalny status regionów wyspiarskich.

Zasada obliczania pułapów dla poszczególnych państw jest instrumentem ograniczającym wysokość transferów dla państw, których poziom rozwoju gwarantuje możliwość finansowania zastosowanych rozwiązań w ich polityce gospodarczej samodzielnie lub z ograniczonym wsparcie ze strony budżetu UE. Rozwiązanie przyjęte w tym zakresie wspomaga również mechanizm redystrybucji dochodów między regionami zamożniejszymi a reprezentującymi niższy poziom rozwoju. Odnosi się to zarówno do rozwiązań wewnętrznych w poszczególnych państwach, jak i do rozwiązań uwzględniających transfery z budżetu UE. Sprzyja temu wprowadzenie maksymalnego pułapu dla wszystkich państw członkowskich na poziomie $2,5 \%$ ich PNB. Pułap ten będzie stosowany na zasadach rocznego naliczania i będzie służył redukowaniu transferów (z wyjątkiem regionów mniej rozwiniętych i współpracy terytorialnej), sprzyjając równocześnie optymalnej alokacji środków finansowych pozostających w dyspozycji UE. Dla państw członkowskich, które dołączyły do UE przed 2013 rokiem i których średni PNB w wartościach realnych w latach 2008-2010 kształtował się poniżej -1\%, ustala się granice dla transferów, zwiększoną o $10 \%$ w stosunku do tej, która obowiązuje pozostałe państwa. W praktyce oznacza to poziom $2,59 \%$ PNB. Dodatkowo przyjmuje się, że obok mechanizmu stosowania pułapów alokacje nie mogą przekroczyć 110\% wartości transferów dla lat 2007-2013.

Interesującym dodatkowym rozwiązaniem zastosowanym w nowych WRF jest wprowadzenie pewnych zabezpieczeń, które stanowią konsekwencję kryzysu 2008+. W praktyce oznacza to wprowadzenie zastrzeżenia dotyczącego pułapu transferów dla regionów, których PNB w latach 2007-2013 kształtował się poniżej 75\% średniej dla UE-25, ale jest powyżej 75\% średniego poziomu dla UE-27, minimalny poziom transferów w latach 2014-2020 w ramach inwestycji we wzrost i tworzenie miejsc pracy określa się na wysokości 60\% wcześniej stosowanej alokacji w ramach stymulowania procesów konwergencji dla lat 2007-2013.

Ustalono również poziom minimalnych alokacji całkowitych dla państw dla transferów z Funduszu Spójności i strukturalnych, wynoszący 55\% poziomu z lat 2007-2013. Wszystkie dodatkowe warunki muszą spełniać przyjęte założenia, 
zgodnie z zasadą proporcjonalności stosowaną w Funduszu Spójności i funduszach strukturalnych. Wyłączeniu podlegają jedynie zasady finansowania celu, jakim jest europejska współpraca terytorialna.

Uwzględnia się również, że żaden region w procesie przemian nie może uzyskać mniej, niż gdyby uzyskał, będąc zaliczonym do kategorii bardziej rozwiniętej. W celu określenia minimalnego poziomu transferów przyjmuje się, że metoda alokacji dla regionów rozwiniętych będzie stosowana dla wszystkich regionów, w których PNB na głowę kształtuje się poniżej 75\% średniej dla UE-27.

Specjalne alokacje przewidziano dla państw najbardziej dotkniętych kryzysem strefy euro, co wpływa na wyraźne obniżenie poziomu stopy życiowej ich ludności. Wychodząc naprzeciw ich potrzebom, przeznacza się z funduszy strukturalnych dodatkowe środki dla:

- Grecji - 1,375 bln euro, dla bardziej rozwiniętych regionów państwa;

- Portugalii - 1,0 bln euro, z czego $450 \mathrm{mln}$ skierowanych zostanie do bardziej rozwiniętych regionów, w tym $150 \mathrm{mln}$ przeznaczonych jest dla Madery, $75 \mathrm{mln}$ - dla regionów w procesie zmian i $475 \mathrm{mln}$ - dla regionów mniej rozwiniętych;

- Irlandii - 100 mln euro, ze wskazaniem granicznych, zachodnich i centralnych regionów kraju jako beneficjentów;

- Hiszpanii - 1,824 bln euro, z czego 500 mln przeznaczonych jest dla Estremadury;

- Włoch - 1,5 bln euro, z czego 500 mln przeznaczonych jest dla obszarów pozamiejskich.

Określone kwoty przeznaczono również dla państw wyspiarskich. Malta i Cypr otrzymają po zastosowaniu pkt. 48 przyjętego na szczycie dokumentu Wniosków końcowych odpowiednio $200 \mathrm{mln}$ i $150 \mathrm{mln}$ euro. Przekazane tym państwom środki pozyskane są z inwestycji we wzrost i tworzenie miejsc pracy. Dodatkowe środki w wysokości $50 \mathrm{mln}$ skierowane będą na Ceutę ${ }^{27}$ i Melillę. ${ }^{28}$ Odległy obszar Mayotee ${ }^{29}$ uzyska 200 mln euro.

Konkluzje ze szczytu zawierają dodatkowo stwierdzenia dotyczące konieczności przeprowadzenia zmian i sprostania długookresowym wyzwaniom rozwoju w wielu regionach. Celom tym podporządkowane sa dodatkowe alokacje, które kieruje się do: - Belgii - 133 mln euro, z czego 66,5 mln euro przeznacza się dla Limburgii, a 66,5 mln dla Walonii;

${ }^{27}$ Hiszpańska jednostka administracyjna. Miasto położone w Afryce na cyplu tworzącym Cieśninę Gibraltarską.

${ }_{28}$ Miasto. Jednostka administracyjna Hiszpanii położona w Afryce Północnej, na wschodnim wybrzeżu Maroka.

29 Zamorski departament francuski, składa się dwóch wysp, Maori i Pamanzi, położonych w północnej części Kanału Mozambickiego (pomiędzy północnym Madagaskarem i północnym Mozambikiem). 
- Niemiec - $710 \mathrm{mln}$ euro, z czego $510 \mathrm{mln}$ przeznacza się dla byłych regionów poddanych konwergencji, a także 200 mln dla Lipska;

- mimo stwierdzeń zawartych w pkt. 45 konkluzji ze szczytu mniej rozwinięte regiony Węgier uzyskały alokację 1,560 bln euro, a Czechy dodatkową alokację $900 \mathrm{mln}$ euro (z czego $300 \mathrm{mln}$ uzyskanych jest z transferu pochodzącego $\mathrm{z}$ alokacji na rozwój obszarów wiejskich); natomiast mniej rozwinięte obszary Słowenii uzyskują dodatkowo $75 \mathrm{mln}$ euro $\mathrm{w}$ ramach funduszy strukturalnych.

Określa się również obowiązki państw członkowskich wynikające z przyjętych zasad finansowania Europejskiego Funduszu Rozwoju. Wprowadza się też poziomy pułapów dotyczące transferów dla poszczególnych grup państw i poziomy pułapów dla ich zobowiązań finansowych. Tak jak w poprzednich wieloletnich ramach finansowych określa się wartość zobowiązań i płatności $\mathrm{w}$ formie procentowego ich udziału w zakumulowanym PNB. Dodatkowo określa się zobowiązania finansowe wynikające $\mathrm{z}$ przyjętych założeń $\mathrm{w}$ działaniach zewnętrznych UE. Choć te wskaźniki kształtują się różnie dla poszczególnych lat, to warto je przedstawić jako wytyczne dla całej perspektywy w okresie siedmioletnim. I tak ogólne zobowiązania finansowe wynoszą 1\% skumulowanego PNB państw członkowskich, natomiast ogólne płatności kształtują się na niższym poziomie i wynoszą 0,95\% skumulowanego PNB. Do tego ułamka dochodzą zobowiązania UE do działań podejmowanych poza przyjętymi WRF. Jeśli chodzi o zobowiązania, to są one szacowane na 0,04\%. Tym samym pełne obciążenia dla państw członkowskich wynikające $\mathrm{z}$ WRF i działań finansowanych poza środkami pozyskanymi w WRF wynoszą dla całej perspektywy $1,04 \%$.

\section{Podsumowanie}

Nowe WRF ukierunkowane są na poprawę spójności w ramach państw członkowskich UE, jednakże elementy zewnętrzne polityki spójności (odnoszące się do państw trzecich, spoza UE) również są brane pod uwagę.

Procesy instytucjonalizacji kontaktów z państwami nieczłonkowskimi Unii Europejskiej i zastosowane w nich rozwiązania wyraźnie wskazują na aspekt poprawy spójności we wszystkich jej obszarach. Niemniej jednak kwestia ta nie znalazła większego odzwierciedlenia w dotychczas przygotowywanych analizach problemu kohezji. Przygotowana w ramach badań Kolegium Ekonomiczno-Spłecznych analiza może być uznana za pionierską w tym zakresie i tym samym przyczynkarską. Nie ulega wątpliwości, że związki między poprawą spójności a procesami instytucjonalizacji 
występują i występowały w przeszłości. We wcześniejszych okresach proces ten m.in. objął przyszłe kraje członkowskie Unii Europejskiej, które uzyskały status członkowski w latach 2004-2007. Warto jednak podkreślić, że nie wszystkie te państwa poprawiły swoje standardy życia i pokonały dystans rozwojowy dzielący je od Unii Europejskiej w takim samym stopniu. Tym samym warto się zastanowić, które z metod pokonywania dystansu należy stymulować, a które traktować jako rozwiązania marginalnie wpływające na urzeczywistnienie celu, jakim jest poprawa spójności. Mamy kilka sfer spójności i każda $\mathrm{z}$ nich jest w pewnym stopniu pochodną pozostałych, należy więc prowadzić badania, które z tych sfer odgrywają wiodącą rolę $\mathrm{w}$ stymulowaniu rozwoju.

\section{Cohesion and institutionalization of cooperation between EU and third countries}

Institutionalization of contacts between EU member stats and third countries influences structural changes in cooperating states, such as convergence of less developed economies to the level of the more developed ones and increase of efficiency of developed economies. All in all the overall level of welfare increases.

The following paper defines cohesion and institutionalization and explains how those two processes are interlinked and what is their effect on economic growth dynamics and on diminishing of growth gap.

Attention is drawn to the dynamic character of contacts between EU and it's neighbors which translates into access to the EU market. Convergence is not limited to transfer of funds, materiel, expertise and know-how. EU acts also as a manager and controller of those processes. However the scope and dynamics of changes are limited in accordance with the political will of third parties. The process of convergence is beneficiary to all sides as their economies expand.

\section{Институционализация связей между ЕС и третьими странами и сплоченность}

Институционализация связей в рамках государств-членов ЕС и с третьими странами (за пределами ЕС) способствует ускорению процесса структурных преобразований партнеров по сотрудничеству. 
В высокоразвитых странах, которые сотрудничают с менее развитыми странами, из-за этих связей происходит сближение (конвергенция) по уровню развития. В странах с более высоким уровнем развития, факторы производста переходят от менее трудоемких и эффективных отраслей производства к более капиталоемких и эффективным отраслям. Это способствует повышению динамики производства добавленной стоимости, что, в свою очередь, влияет на повышение уровня общего благосостояния. Однако, если описание предпринимаемых в данной экономике мероприятий, будет сосредоточено исключительно на процессах структурных изменений, их восприятие приведет к описанию текущих расходов и не будущих выгод. Такая картина не будет объективной, тем не менее, достаточно часто таким образом проводятся анализы. Тем самым, их результаты вместо укрепления процессов интеграции на разных уровнях международных отношений могут их тормозить. Текст включает дефиницию когезии, то есть сплоченности, институционализации и объясняет каким путем эти два процесса связаны и каковы их эффекты для динамики экономического роста и преодолевания разрыва в уровне развития.

В тексте обращается внимание на тот факт, что процесс отношений ЕС со своими соседями имеет динамический характер. Это означает, что соседние страны за короткое время могут присоединиться к единому внутреннему рынку. При этом конвергенция не означает только передачи партнером средств, капитала, знании и ноу-хау. ЕС выступает также в роли менеджера и контроллера этих процессов. Тем не менее, степень и динамика изменений зависят от политической воли страны сотрудничающей с ЕС. Процесс конвергенции основанной на институционализации, приспособлении законодательства, экспертизах, экспертах и передаче ПИИ выгоден для обоих партнеров. В государстве с более низким уровнем развития растет капитал в капиталоемком производстве. Растет потенциал человеческого капитала. Наоборот в противоположном направлении. В обмене богатый - бедный: структурные изменения в высокоразвитых государствах благоприятствуют их обогащанию. Однако, это не «игра с нулевой суммой», в которой выигрыш одной стороны это проигрыш второй. Оба партнеры выигрывают. Убедился в этом Китай и часть государств в регионе Центральной и Восточной Европы. 